Polgári Szemle, 16. évf. 1-3. szám, 2020, 378-391., DOI: 10.24307/psz.2020.0722

Vladislava Poletaeva - Alexey Smulov - Szabolcs Pásztor

\title{
Financial Mechanism of Forming an Economic System of Sustainable Industrial Growth in Russia
}

Summary

This study aims to identify a potential mechanism to enable transformation of Russia's economy from the inefficient export-oriented and raw-materials-based model into an economic system of sustainable industrial growth. Based on the studies done by Russia's leading researchers, a conclusion was made that in order to reach the objective it is necessary to activate financial mechanisms. Due to a variety of challenges that emerge in the implementation of the financial mechanisms available, the authors propose a scheme based on collaboration between the banking sector and the state that will ensure the interests of the three key participants to an investment project - a bank, a manufacturing company and an authorised government institution. This mechanism can be a promising alternative to bank- or public-only financing of the economy, as it factors in their advantages. This article analyses the interests of stakeholders of the bank and the manufacturing company. Based on the analysis, the authors set the task to optimise determining the extent banks and authorised government institutions should participate in project financing with due account taken of the credit institution's risk minimisation and achieving acceptable profit levels.

Vladislava Poletaeva, Plekhanov Russian University of Economics, Russia (poletaeva_vladislava@mail.ru), Alexey Smulov, private educational institution of higher education Saint Tikhon's Orthodox University for the Humanities, Russia, Szabolcs Pasztor, National University of Public Service, Hungary (szabolcs.pasztor@uni-nke.hu) 
Journal of Economic Literature (JEL) codes: C5, G21, G32

Keywords: financial mechanism, economic system of sustainable industrial growth, investment project, stakeholder, banking sector, state, government, manufacturing industry sectors.

\section{INTRODUCTION}

Relatively low growth rates have, in recent years, been characteristic of the economic development of some countries, in particular, the Russian Federation, a number of the European Union countries (including France, Germany, the United Kingdom and Italy), Japan, Brazil, Mexico and many others among them. The growth rates of some economies are not only low, but also unsustainable to a large extent. With a view to assess the sustainability of economic growth rates, the authors propose to use the approach of the United Nations Industrial Development Organization (UNIDO) which factors in the following criteria: 1) the average per capita GDP growth rates; 2) duration of economic growth periods; 3 ) volatility (variability) of economic growth.

The research done by the authors against the above listed criteria suggests that economic growth in some countries, primarily the transition economies, with Russia currently among them, is characterized by a high degree of instability.

A variety of factors (socio-economic, political, geopolitical, etc.) and, not least of all, external with respect to the national economic system have a significant adverse effect on the sustainability of Russia's economic growth. This instability is caused by high dependence of economic growth on the world commodity and financial markets conditions, low industrialization, the export-oriented and raw-materials-based economic model, etc.

In the authors' opinion, overcoming the dependence of the Russian economy on the negative impact of external factors may facilitate its transition to a model of sustainable industrial growth. At the same time, an economic system of sustainable industrial growth is recognized as one, whose industrial sector output increases on a permanent basis over a long period of time and its dynamics, and, which, in spite of being subject (to some extent) to the negative impact of various factors, including external ones, is capable to offset such adverse impact. The economic system of sustainable industrial growth is based on technologically advanced manufacturing with high labor productivity enabling to increase the output of products competitive in both domestic and international markets.

To transform the national economy from the inefficient export-oriented and rawmaterials-based model into a system of sustainable economic growth, it is essential to address a number of issues, the most important of which are a low share of processing industries in the structure of gross added value, as well as the renovation of the morally and physically obsolete material, technical and engineering capability of the Russian industry. 
Vladislava Poletaeva - Alexey Smulov - Szabolcs Pásztor: Financial Mechanism...

POTENTIAL MECHANISMS OF FORMING AN ECONOMIC SYSTEM OF

SUSTAINABLE INDUSTRIAL GROWTH AND ISSUES HINDERING

THEIR IMPLEMENTATION

Most of the leading Russian researchers (Aganbegyan et al., 2014; Aganbegyan, 2016; Maevskij, 2000; Smulov, 2009) agree that activation of financial mechanisms will enable to resolve the above mentioned issues and transition to the economic system of sustainable industrial growth. Already the mercantilists and subsequently proponents of the classical political economy (Majburd, 1996) viewed increasing cash flows underpinning these mechanisms as one of the most important ways to address economic issues.

According to J. M. Keynes's theory (1936), financing, through new jobs creation and consumer spending growth, provides a multiplicative increase in gross domestic product (GDP).

Despite the high importance of financial mechanisms (according to a number of leading researchers) in driving the economic system's sustainable growth, the Russian economy has been functioning, over a quarter of a century, against the backdrop of a relatively low investment activity of its economic agents. In Russia, the share of fixed assets investments in GDP from 1991 to 2017 did not exceed 20.2\% (in 2007), and amounted to $17.35 \%$ at the end of 2017 . According to the research by A. G. Aganbegyan, academician of the RF Academy of Sciences (Aganbegyan et al., 2014), many industrial sectors employ the production technologies used in the industrialized countries 20-30 years ago. According to this scholar, the use of outdated fixed assets and production technologies in Russia has resulted in a 2.5-3-fold drop in labor productivity in comparison with the countries of Western Europe and the United States, and a 1.5-2-fold higher energy- and material production intensity, on average, compared with the above countries.

Ensuring stable economic growth rates in Russia based on a highly developed industrial sector, comparable, at least, with the growth rates in the European Union, the United States and Canada, necessitates a significantly higher investment activity by economic actors. The share of investment in GDP should be increased, at least to the level observed in the abovementioned industrialized countries, i.e. by at least $\$ 100-115$ billion; and given a significant resource demand that has accompanied the national economy's development over a long period of time, even to a higher level.

Another significant challenge in organizing resource investment in the Russian economy is an extremely low investment in intellectual property, as well as very limited resources allocated to cover the costs of research, development and technological work.

Moreover, there is a strong imbalance in distribution of funds by types of economic activity. Thus, the largest amount of funding has been allocated, for over 20 years, to the sectors engaged in mining mineral resources, transportation and product storage as well as real estate operations. However, the processing industries, significant for transition of the Russian economy to a sustainable industrial growth model, accounted between 1995 and 2017 for no more than $16.4 \%$ of investment. $^{1}$ 
Among other things, companies mainly use their own funds to finance their investments. Though self-financing as a source of investment offers certain advantages (high availability, the pseudo-low price of resources use, the ability of the founders to retain the ownership and management structure, etc.), it also has some disadvantages. These shortcomings include, in particular, significantly limited investment opportunities, occasional unreasonable withdrawal of funds from the economic turnover of the enterprise, a lack of independent oversight of investment efficiency, or a significant time lag between investment and the exercise of independent oversight.

At the same time, the share of investments by financial intermediaries, primarily banks, is extremely low: between 1995 and 2017 it averaged 10.9\%, while this figure, according to experts, was, for example, $30-50 \%$ in the U.S. and Germany and about $20 \%$ in China (Aganbegyan, 2016).

The challenges described above in organizing investment in the Russian economy, as well as the urgent need for its rapid transition to a model of sustainable industrial growth are indicative of the need to develop new financial mechanisms.

The first step on the way to resolve this issue is identification of sources enabling to increase investment in manufacturing industries.

\section{SOURCES OF INCREASING INVESTMENT IN MANUFACTURING INDUSTRIES}

The funds of the Russian banking sector, as well as the public funds, may become the financial basis for implementing this undertaking.

Thus, according to the financial data reported by Russian credit institutions, 11 systemically important banks alone (which hold about $60 \%$ of the country's banking sector's assets) concentrated nearly $\$ 100-\$ 115$ billion of temporarily uncommitted resources in 2018. ${ }^{2}$ The funds were kept on NOSTRO correspondent accounts, highly liquid assets of the interbank market as well as cash in the vaults of these credit institutions.

The government currently has even more funds at its disposal. Thus, it has at its disposal the resources of the National Welfare Fund as well as gold and foreign exchange reserves, which in 2018 totaled between from $\$ 410$ to $\$ 502$ billion (at the beginning of each quarter). ${ }^{3}$ These funds are currently invested in highly liquid international financial assets (foreign exchange, gold, securities of foreign issuers, etc.). In addition, the government (by virtue of its status) has the authority to increase revenues of the budgetary system through, for example, making efficient changes in the tax policy it pursues.

In addition to the resources of the state and the banking system, the Russian population also holds significant funds. Thus, the volume of the Russian citizens' savings in cash was about $\$ 71-\$ 85$ billion in $2018 .^{4}$ These funds are a potential source of replenishing the banking sector's resource base, as well as revenues of the RF budget through borrowing mechanisms implementation. 
Vladislava Poletaeva - Alexey Smulov - Szabolcs Pásztor: Financial Mechanism...

THEORETICAL AND METHODOLOGICAL FOUNDATIONS OF THE

FINANCIAL MECHANISM OF FORMING AN ECONOMIC SYSTEM OF

SUSTAINABLE INDUSTRIAL GROWTH

1) Substantiating the rationale for enhancing cooperation between the banking sector and the state in manufacturing industry financing.

The specifics of the Russian banking sector's lending and investment activities arrangement indicate that the credit institutions do not seek to increase investment, primarily of a long-term nature, in the Russian industry. There are a number of reasons for the low relevance of such operations. These include, inter alia, the following: 1) significant risks inherent in such investments (credit, loss of liquidity, interest rate, etc.); 2) low credit and deposit margins taking into account even the official inflation rate; 3) availability of alternative investment options (government and corporate securities, interbank credits, etc.).

Therefore, bank investments are, to a large extent, of a short- and medium-term nature, the interest rates levels make the resources significantly less affordable for borrowers, while the quality of loan arrears portfolios continues to be low.

At the same time, bank loans as a source of financing investment in the economy offer a number of advantages. These advantages are due to the banks' specialization in providing funds on the terms of urgency, repayment, interest payment and other principles of lending. As professional lenders, banks (unlike a number of other economic agents, including the state) have the technologies to analyze a borrower's activities, taking into account its financial standing, the quality of debt servicing, as well as all the available information about the funding recipient, including potential risks; they also have qualified employees capable of performing such analysis.

Credit institutions can select the most efficient investment projects; assess the solvent demand of enterprises for resources; determine the lending conditions acceptable both in terms of ensuring the borrower's progress as well as a full and timely repayment of the borrowed funds; they can also monitor the targeted use of received financing.

In view of the above, raising the interest of the banking sector in increasing investments in manufacturing industries is a topical undertaking. To address this task it is imperative to identify an entity that has a vested interest in the economy's transition to a sustainable industrial growth model and the banking sector development and capable to provide financing conditions that meet the needs of both credit institutions as well as manufacturing companies. The state may be such an entity represented by various-level legislative and executive bodies and by the Central Bank.

The interest of the state follows from its mission and the functions vested therein, including, inter alia, defining the economic strategy's objectives, economic activity regulation, creating a favorable environment for economic growth and development, etc. These functions are discharged through development (adoption) of regulatory acts governing various aspects of the national economic system, their enforcement or 
oversight of their implementation by other economic agents and imposition of various penalties on violators.

These acts govern the rights and obligations of parties to various economic relations, forms of capital ownership, the operation of the budget, tax and banking systems as well as branches of the real sector; inflation regulation, the economy's state support programs, etc.

In addition to fulfilling its mission the state can realize, by financing promising industries, its interest in increasing the budgetary and state extra-budgetary funds revenues through tax and other receipts from banks and manufacturing.

It should be emphasized that to reach the objective of transforming the economic model into one of sustainable industrial growth, it is essential to define a clear-cut strategy of state regulation of the economy geared towards achieving this objective and to design a plan featuring tactical measures to implement the strategy. Moreover, it is essential, for the successful implementation of this task, to ensure coordinated efforts of various authorities, as well as the possibility to spend a reasonable part of the National Welfare Fund's resources held by the state, gold and currency reserves and other funds. The low effectiveness of the ongoing programs to support the national economy' sectors and individual enterprises highlights a demand for these measures.

Therefore, the financial mechanism of forming an economic system of sustainable industrial growth is based on realization of interests of each party involved: manufacturing companies, the banking sector and the state. The theoretical and methodological basis for this idea is the stakeholder concept, which has been gaining ground in the management theory (primarily in foreign research literature) in recent decades. A far-from-complete list of its proponents includes Alkhafaji (1989), Clarkson (1995), Freeman and Reed (1983), Mitchell et al. (1997), and many others.

The essence of this concept is that each of the stakeholders has the right to be heard and understood, since these parties are equal in addressing emerging economic and social issues and challenges.

\section{2) Identifying stakeholders and their interests in manufacturing projects financing.}

There is no uniform definition of a stakeholder in the research literature. As a rule, stakeholders are individuals, as well as their groups or clusters, who, for a variety of grounds, have rights, claims on and interests in respect of a certain entity, who exert influence on this entity and, at the same time, are dependent on it.

In the economy, the objects of influence may be individual companies, industries, sectors, national or global economic systems, as well as monetary resources or other assets, mechanisms, projects, processes, etc. Therefore, stakeholders are the population (households), enterprises, organizations, banks and financial companies, industries, sectors, the state, etc.

Stakeholders have claims on or interests in respect of the object of law, for example by virtue of regulatory acts, contracts (sales, licensing, lending ones, etc.) and on other grounds. 
Vladislava Poletaeva - Alexey Smulov - Szabolcs Pásztor: Financial Mechanism...

The financial mechanism of forming a system of sustainable industrial growth is implemented through investments by banks and the state (represented by an authorized institution) in manufacturing enterprises' projects. In this case the stakeholders have a vested interest in the investment project implementation.

A definition of project stakeholders is provided in the ANSI PMI PMBOK Standard, according to which, they are individuals actively involved in the project implementation or whose interests may be affected both positively and negatively during its implementation or as a result of its completion. They are capable to influence the project, its outcomes and team members. Therefore, stakeholders, in our case, are the manufacturing company, the bank and the authorized government institution (at an individual project level) and manufacturing industries, the banking sector and the authorized state institution (at a group of funded projects level).

In order to design investment terms meeting the project's stakeholder requirements, it is essential to identify their interests. The interest of the authorized state institution lies, obviously, in developing manufacturing industries and the banking sector. The interests of the bank and the industrial enterprise are more ambiguous as a significant number of stakeholders have a vested interest in these economic actors.

However, the stakeholders have a varying degree of influence on the activities of the parties to the investment project. Therefore, it is essential to identify the persons that exert the greatest influence on banks and industrial enterprises.

Such stakeholders can be identified using Mitchell's model of saliency determination which has been widely used in today's economic literature. Three attributes characterize a stakeholder under the model: legitimacy, power and urgency of its claims.

By "legitimacy", Mitchell understands a general idea or assumption that a stakeholder's actions are desirable, correct or appropriate from the viewpoint of the social norms, values, beliefs and definitions. The author of the model defines "power" as the relationship between economic agents by virtue of which one of them, due to the availability (or possibility of obtaining) access to coercive, utilitarian or regulatory means, influences the other; while "urgency" means the length of time within which the obligations of the stakeholders are to be fulfilled.

Under Mitchell's model, stakeholders are divided into seven groups, based on the presence or absence of the above attributes:

1) Power only (latent);

2) Legitimacy only (independent);

3) Urgency only (demanding);

4) Power and legitimacy (dominant);

5) Power and urgency (dangerous);

6) Legitimacy and urgency (dependent);

7) Lower, legitimacy and urgency (definitive).

The first three groups of stakeholders usually have very limited, if any, power to influence the company's operations; for example, recipients of support provided by the company (institute) under charity programs or managers of newspapers, TV channels, etc. 
Dominant, dangerous and dependent stakeholders are capable to exert a much greater influence on the company operations, as the two attributes they possess make the company more sensitive to their needs. These stakeholder groups include, for example, strikers, environmentalists, the general public, etc.

The most important ones for the company (institution) are those with all three attributes who make up the dominant group, for example, shareholders, managers, etc.

Table 1 presents the bank's potential stakeholders, grouped according to the presence of certain attributes. Table 2 features the manufacturing companies. The groups are ranked in a descending order from those with the highest to the least influence on the activities of the abovementioned credit project participants.

Table 1: Stakeholders of credit institutions

\begin{tabular}{|c|c|c|c|c|c|}
\hline Stakeholder & $\begin{array}{c}\text { Functioning } \\
\text { level }\end{array}$ & Power & Legitimacy & Urgency & $\begin{array}{c}\text { Stakeholder } \\
\text { group }\end{array}$ \\
\hline $\begin{array}{l}\text { Government - } \\
\text { federal agencies; regional } \\
\text { authorities; local authorities }\end{array}$ & $\begin{array}{l}\text { Macro level } \\
\text { Meso level } \\
\text { Micro level }\end{array}$ & + & + & + & \multirow[t]{3}{*}{ Definitive } \\
\hline Owners & Micro level & + & + & + & \\
\hline Managers & Micro level & + & + & + & \\
\hline General public & Macro level & + & + & - & \multirow{3}{*}{ Dominant } \\
\hline Competitors & Micro level & + & + & - & \\
\hline Insiders & Micro level & + & + & - & \\
\hline Mass media & Meso level & + & - & - & Latent \\
\hline Employees & Micro level & - & + & + & \multirow{8}{*}{ Dependent } \\
\hline Investors & Micro level & - & + & + & \\
\hline Borrowers & Micro level & - & + & + & \\
\hline Other customers & Micro level & - & + & + & \\
\hline Other counterparties & Micro level & - & + & + & \\
\hline Issuers & Micro level & - & + & + & \\
\hline Branches & Micro level & - & + & + & \\
\hline Suppliers & Micro level & - & + & + & \\
\hline
\end{tabular}

Source: Compiled by the authors

According to the data in Tables 1 and 2, the main stakeholders of both banks and manufacturing companies are their owners, managers and the state. Let us consider in more detail the interests stakeholders pursue when influencing companies.

Owners (shareholders, participants and founders) are individuals or legal entities who own the company equity. Their authority covers the most important matters in the banks and industrial enterprises' activities, including, for example, reorganization or liquidation of the credit institution and the manufacturing enterprise, increase or 
Vladislava Poletaeva - Alexey Smulov - Szabolcs Pásztor: Financial Mechanism...

Table 2: Stakeholders of manufacturing companies

\begin{tabular}{|c|c|c|c|c|c|}
\hline Stakeholder & $\begin{array}{c}\text { Functioning } \\
\text { level }\end{array}$ & $\begin{array}{l}\text { Po- } \\
\text { wer }\end{array}$ & Legitimacy & Urgency & $\begin{array}{c}\text { Stakeholder } \\
\text { group }\end{array}$ \\
\hline $\begin{array}{l}\text { Government - } \\
\text { federal agencies; regional } \\
\text { authorities; local authorities }\end{array}$ & $\begin{array}{l}\text { Macro level } \\
\text { Meso level } \\
\text { Micro level }\end{array}$ & + & + & + & \multirow[t]{3}{*}{ Definitive } \\
\hline Owners & Micro level & + & + & + & \\
\hline Managers & Micro level & + & + & + & \\
\hline General public & Macro level & + & + & - & \multirow{3}{*}{ Dominant } \\
\hline Competitors & Micro level & + & + & - & \\
\hline Insiders & Micro level & + & + & - & \\
\hline Mass media & $\begin{array}{c}\text { Medium } \\
\text { level }\end{array}$ & + & - & - & Latent \\
\hline Employees & Micro level & - & + & + & \multirow{6}{*}{ Dependent } \\
\hline Suppliers and contractors & Micro level & - & + & + & \\
\hline Buyers and customers & Micro level & - & + & + & \\
\hline Creditors & Micro level & - & + & + & \\
\hline Other counterparties & Micro level & - & + & + & \\
\hline Branches & Micro level & - & + & + & \\
\hline
\end{tabular}

Source: Compiled by the authors

decrease of its charter capital, dividend payments (announcements) based on the performance in a certain reporting period, etc. By virtue of their status, owners have the authority to enforce their decisions, which are, in general, legitimate and enforceable within a certain period of time.

The owners' strategic interests include, in particular, increasing the value of the business, i.e. the value of the company's property complex (assets) capable to generate profits to its owners, increasing the competitiveness of the credit institution and the enterprise, maintaining its goodwill, etc.

One of their most important tactical interests is the growth of (net, undistributed) profit, as it is the profit that finances the company development costs as well as dividend payments or the owners' other income. Moreover, owners usually aim to secure an acceptable level of transaction risk, expand business activity, etc.

As a rule, managers are individuals, usually employees, who manage the entire company or its units.

There are three levels of managers:

1) Top managers (sole and collegiate executive bodies of companies). Top managers provide operational management of credit institutions (industrial companies), they dispose of their property, enter into contracts with counterparties, issue various orders concerning the company activities, consider and approve the company devel- 
opment plans, monitor the performance of the bank's (manufacturing company's) subdivisions. It should be noted that senior executives' functions can be performed not only by individuals, but also legal entities, the so-called management companies;

2) medium-level (managers of major structural units - directorates, departments, branches, etc.);

3) lower-level (heads of small units, for example, worker teams or groups, etc.)

Middle- and lower-level managers are responsible for the day-to-day running of the units they are in charge of. This group of stakeholders (as well as owners), have, by virtue of their status, certain powers and their decisions are also legitimate and subject to execution within a certain period of time.

One of the managers' key interests is their income growth, which can be secured, in particular, through various types of bonuses and rewards (share of profits payments) as well as salary raises. Bonus and reward payments are manly contingent on the achievement (or outperformance) of the targets set in the company development plans and are usually funded from the company net profit. Therefore, managers as well as owners, have a vested interest to grow the credit institution's (industrial company's) profits, to secure an acceptable operational risk, expand the company' operations , maintain its goodwill, raise its competitiveness, etc.

It should be emphasized that any-level managers can, at the same time, be company owners (minority ones inclusive). In such case they may have a varying degree of interest (depending on their holding in the company equity and the position held) to grow their income through dividends or bonuses based on their performance and to use company profits to increase funding of its activity.

The state as an economic agent performs certain functions, one of which is the regulation of various processes in the socio- economic area. As a result, the government, represented by the authorized bodies (the RF Federal Assembly, the RF Government, the Bank of Russia, the RF Ministry of Finance, the Federal Tax Service, regional authorities, etc.) exerts influence on companies (exercises the authority over them) using various instruments.

Thus, credit institutions for example are obligated to comply with certain mandatory ratios, effect transactions in compliance with the instructions of the regulatory authority, etc. The state also regulates various aspects of manufacturing enterprises operation through establishing, for example, rules for performing certain activities. Moreover, companies need to transfer taxes and other mandatory payments to the RF budgetary system and extra-budgetary funds. These requirements are defined by the regulatory documents, are fully legitimate and also urgent.

The list of government interests in this case is quite diverse - to increase stability (including financial) and efficiency of the banks and industrial enterprises, to reduce risks of their operations, to ensure inflow of tax revenues to the budget and extrabudgetary funds, etc.

Moreover, the state, represented by its authorized bodies, may act as the owner of credit institutions and enterprises, as well as a depositor, creditor or other type of investor in such companies and have its own interests. 
Vladislava Poletaeva - Alexey Smulov - Szabolcs Pásztor: Financial Mechanism...

It is obvious that in realizing the interests of the above stakeholders, both banks and manufacturing companies will aim to increase the value of their business, increase their profits, secure acceptable risk of operations, maintain their companies' goodwill, enhance their competitiveness, comply with the regulatory and other requirements of the state, etc. A competent design of an investment project which factors in the above interests of credit institutions as well as manufacturing companies can, in the authors' opinion, promote inflow of bank investment to manufacturing companies and, at the same, enhance funds availability for recipients. Therefore, their interests should underpin the mechanism developed in the framework of this study.

As noted above, growth of the businesses value, companies' increased competitiveness and building their goodwill are also part of the strategic interests of banks and manufacturing companies. Achievement of these objectives depends on a significant number of factors that cannot be taken into account in determining the conditions for company financing.

Therefore, the proposed mechanism primarily takes into account companies' tactical needs, i.e. increasing profits, expanding the scope of business, maintaining risks at an acceptable level and compliance with the statutory requirements. At the same time, meeting tactical needs significantly contributes, in our opinion, to achieving the abovementioned strategic interests of banks and industrial companies.

\section{3) Aligning the interests of the bank and the authorized state institution}

In order to implement the mechanism of forming an economic system of sustainable industrial growth, it is essential to define, among other, conditions on which banks and authorized government institutions will participate in industrial companies' project financing (specifically, a participation share of each creditor); which conditions should also secure to the bank acceptable profit levels, limited risk of resource investment (i.e. credit, interest and liquidity risks) and compliance with the requirements of the regulatory body. Conditions of creditor participation in projects can be specified through optimizing company financing (Egorova-Smulov, 2001; Sinki, 1994).

Below is the model developed by the authors enabling to optimize coordination of participation shares of the bank and the authorized government institution in industrial company financing.

$$
\begin{aligned}
& X_{i j}=X b_{i j}+X g_{i j} ; \\
& X_{i j} \leq R_{i j} ; \\
& X g_{i} \leq D g_{i j} ; \\
& X b_{i j} \leq \min \left(D b_{i j} ; R_{i j} ; C B_{i j}\right) ; \\
& \left(L L P_{i j}-Z_{i j}\right) X_{i j} \geq 0, L R_{i j} \leq 50 \% * X b_{i j} ; \\
& r 1.0 \leq 8 \% ; \\
& r 1.1 \leq 4,5 \% ; \\
& r 1.2 \leq 6 \% ;
\end{aligned}
$$




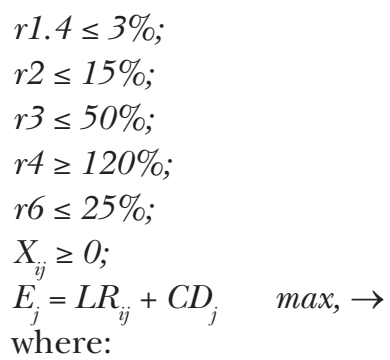

$i$ - a type of loan extended to an industrial company. Three types of credits are considered in this task - short-term (under 1 year); medium-term (from 1 to 3 years) and long-term (over 3 years);

$j$-an industrial company - the loan recipient. The authors consider only manufacturing companies as loan recipients;

$X_{i j}$ - the volume of $i$-type loans extended to company $j$, financed by the bank and the authorized government institution;

$X b_{i j}$ - the volume of $i$-type loans extended to enterprise $j$, financed by the bank;

$X g_{i j}$ - the volume of $i$-type loans extended to enterprise $j$, financed by an authorized government institution;

$R_{i j}$ - borrowing requirements of enterprise $j$ in $i$-type loans, evidenced by a feasibility study, evaluated by the bank and the authorized government institution (manufacturing company's solvent demand);

$D g_{i j}$ - volume of $i$-type loans the authorized government institution is capable to extend to manufacturing company $j$ by decision of its governing body;

$D b_{i j}$ - volume of $i$-type loans the bank is capable to extend to manufacturing company $j$ by decision of its governing body (if such a decision is available);

$C B_{i j}$ - volume of $i$-type loans the bank is capable to extend to manufacturing company $j$ in compliance with the Bank's of Russia mandatory ratios;

$L L P_{i j}$ - loan and loan- equivalents loss provisions calculated in compliance with the Bank's of Russia regulations (Bank of Russia, 2017b);

$Z_{i j}$ - expected average $i$-type credit loss in the sector of manufacturing company $j$ operation (based on statistical analysis of non-performing loans the bank had in the borrower company's economic sector in the previous periods);

$r 1.0, r 1.1, r 1.2, r 1.4, r 2, r 3, r 4, r 6$ - the following statutory ratios established by the Bank of Russia (respectively): the bank's capital adequacy ratio, bank's common capital adequacy, Tier 1 capital adequacy, capital leverage ratio, quick liquidity ratio, current liquidity ratio, long-term liquidity, maximum risk per borrower or group of related borrowers. They are calculated in compliance with the instructions of the Bank of Russia (Bank of Russia, 2017a).

$E_{j}$ - sales revenues of manufacturing company $j$ from the sale of products whose production was financed by the bank and the authorized government institution;

$L R_{i j}$ - part of the sales revenues of manufacturing company $j$, allocated to payback the principal and interest on $i$-type loan to the bank and the authorized government institution; 
Vladislava Poletaeva - Alexey Smulov - Szabolcs Pásztor: Financial Mechanism...

$C D_{j}$ - part of the sales revenues of manufacturing company $j$, remaining in its disposal after the discharge of its obligations to the bank and the authorized government institution under $i$-type loans.

\section{Conclusions}

1. Among significant issues of national economic systems functioning, especially transition economies, is their significantly unsustainable economic growth rates. One of such countries is Russia, where such volatility is caused by the ineffective raw-materials-based and export-oriented economic model, with its economy extremely susceptible to the negative impact of various external factors. Transition of the country's economic system to a sustainable growth model can address this problem.

2. Activating mechanisms of manufacturing industries financing can secure such a transformation. However, a number of obstacles currently hamper implementation of such mechanisms in Russia: investments fail to meet the economy's demand, a disproportionate distribution of investment among the sectors, the fact that companies use mainly their own resources to finance development.

3. In view of these issues, a promising area for promoting financing mechanisms in manufacturing industries is cooperation between the banking sector and the state with due account taken of the interests of key stakeholders of the investment project the bank, the authorized state institution, and the industrial enterprise.

4. The task set by the authors to coordinate the participation shares of the bank and the authorized government institution will secure optimal, in terms of the bank's investment risk limits, credit provision as well as generation of acceptable profits.

\section{Notes}

Official site of the Federal State Statistic Service: www.gks.ru.

Official site of the Central Bank of Russian Federation: www.cbr.ru.

3 Official site of the Ministry of Finance of Russian Federation: www.minfin.ru/ru; official site of the Central Bank of Russian Federation: www.cbr.ru.

4 Official site of the Federal State Statistic Service: www.gks.ru.

\section{REFERENGES}

Bank of Russia (2017a): Bank of Russia Instruction No. 180-I, dated 28 June 2017, “On Banks' Required Ratios".

Bank of Russia (2017b): Bank of Russia Regulation No. 590-P, dated 28 June 2017 "On the procedure for making provisions by credit institution for loans and loan-equivalents".

Aganbegyan, A. G. (2016): Financial Forcing Economic Growth from Recession and Stagnation. Money and Credit, No. 12, 46-52.

Aganbegyan, A. G. et al. (2014): Perspective Lines of Industrial in Russia. Ranhigs, Moscow.

Alkhafaji, Abbass F. (1989): A Stakeholder Approach to Corporate Governance. Managing in a Dynamic Environment. Quorum Books, New York. 


\section{Polgári Szemle · 16. évfolyam 1-3. szám}

Clarkson, Max B. E. (1995): A Stakeholder Framework for Analyzing and Evaluating Corporate Social Performance. Academy of Management Review, Vol. 20, No. 1, 92-117, https://doi.org/10.5465/ amr.1995.9503271994.

Egorova, N. E. - Smulov, A. M. (2001): Companies and Banks. Cooperation, Economic Analysis and Modeling. Delo, Moscow.

Freeman, R. Edward - Reed, D. L. (1983): Stockholders and Stakeholders: A new Perspective on Corporate Governance. California Management Review, Vol. 25, No. 3, https://doi.org/10.2307/41165018.

Keynes, John M. (1948): The General Theory of Employment, Interest and Money. Macmillan, Cambridge.

Maevskij, V. I. (2000): To Deal with Quasi-Market Economy by Quasi-Market Method. Economics of Contemporary Russia, Vol. 1, No. 5, 27-29.

Majburd, E. M. (1996): Introduction to History of Economic Thoughts. From Prophets to Professors. Delo, Moscow. Mitchell, Ronald K. - Agle, Bradley R. - Wood, Donna J. (1997): Toward a Theory of Stakeholder Identification and Salience: Defining the Principle of Who and What Really Counts. Academy of Management Review, Vol. 22, No. 4, 853-886, https://doi.org/10.3138/9781442673496-014.

Sinki, J. jr. (1994): Financial Management in Commercial Banks. Catallaxy, Moscow.

Smulov, A. M. (2009): Industrial Companies and Banks. Cooperation and Crisis Management. Finance and Statistics, Moscow. 